\title{
The effect of fermentation duration and starter concentration on physico- chemical properties of modified sorghum flour by Lactobacillus plantarum FNCC 0027
}

\author{
${ }^{1}$ Kurniadi, M., ${ }^{2}$ Arsyad, M.F., ${ }^{2}$ Sari, A.M., ${ }^{1}$ Nurhayati, R. and ${ }^{1, *}$ Wiyono, T. \\ ${ }^{1}$ Research Unit for Natural Product Technology, Indonesian Institute of Sciences (BPTBA LIPI) \\ Gunungkidul, Yogyakarta, Indonesia \\ ${ }^{2}$ Faculty of Agricultural, Universitas Sebelas Maret, Surakarta, Indonesia
}

Article history:

Received: 21 February 2019

Received in revised form: 18 March 2019

Accepted: 19 March 2019

Available Online: 27 March 2019

\section{Keywords:}

Sorghum,

Lactobacillus plantarum,

Physico-chemical

DOI:

https://doi.org/10.26656/fr.2017.3(5).098

\begin{abstract}
Sorghum was one of the potential crops to be developed as a food product due to its promising nutritional content. The challenges of sorghum utilization are the high amount of tannin content and its low digestibility. Processing methods such as fermentation are known to able to reduce the tannin content, increase the nutrient content and digestibility, as well as the sensory score of sorghum flour. The aim of this study was to find out the effect of fermentation duration and starter concentration of Lactobacillus plantarum on its chemical and physical properties of modified sorghum flour. The study used Completely Randomized Factorial Design with two samples replication and three repetitions of analysis. Ash, moisture, soluble protein, reducing sugar, tannin content, viscosity, white color intensity, and granule size were evaluated to assess its properties. The obtained data showed that the application of L. plantarum significantly reduced the moisture, ash, reducing sugar, and tannin content, but raised the soluble protein $(\mathrm{p}<0.05)$ of sorghum flour and made starch granules to be coarser. The strongest effect was achieved at the condition of $6 \%$ starter concentration and $30 \mathrm{hrs}$ of fermentation. This treatment gave a beneficial effect on sorghum protein digestibility.
\end{abstract}

\section{Introduction}

Nowadays, sorghum becomes one of the top rank promising cereal in the world (Faith, 2017). It is highly potential due to its adaptation capability among various land types (Craufurd et al., 1999) and as an enhancer for alcohol production (Chay et al., 2018). As food, sorghum has a nutrient content almost equivalent to other cereals. In addition, sorghum has other advantages, i.e. its low gluten content and low glycemic index (GI) (Suarni, 2016).

The problem in the use of sorghum is the high content of tannin ranging from $1-6.8 \%$ according to previous study (Arendt and Zannini, 2013). Even though tannin has antioxidant activity (Samirana et al., 2016), it also inhibits proteins involved in food digestion. Tannin forms complex bounding with them and alter their activity on digesting food (Widowati et al., 2014; Wiyono et al., 2018). Another obstacle in raw sorghum is the low digestibility of sorghum starch and proteins (Utami et al., 2015). It is known that the factors causing low sorghum protein digestibility consist of exogenous factors (seed structure and interaction of proteins with non-proteins) and endogenous (disulfide and nondisulfide cross bonds, kafirin hydrophobicity and changes in secondary protein structure) (Duodu et al., 2002). Disulfide cross-linked protein i.e. kafirin in the matrix of starch granules was reported as a major factor of starch's low digestibility (Ezeogu et al., 2013).

Simple processing methods such as husking, fermentation, cooking, germination, enzymatic reactions and fermentation, have been used to reduce the content of tannins in sorghum (Schons et al., 2012). Some studies said that application of fermentation to sorghum can reduce its anti-nutrient such as tannin but increase the nutrient content and its digestibility (Alka et al., 2012; Nour et al., 2015; Adeyemo et al., 2016; Ojha et al., 2018). The fermentation process can also improve the texture of sorghum flour such as reducing the sandy sensation, dryness and hardness of crumb bread (Schober et al., 2007).

Lactobacillus plantarum was reported to give an improvement on flour characteristic of various foodstuffs such as soybean (Amadou et al., 2010), cassava (Frediansyah and Kurniadi, 2016) and sorghum (Pranoto 
et al., 2013). However, to date, there are no reports about the optimized combination of fermentation duration and starter concentration, particularly L. plantarum, producing better characteristic of modified sorghum flour.

In this study, raw sorghum flour was fermented using L. plantarum in order to determine the effect of fermentation on the characteristics of modified sorghum flour produced.

\section{Materials and methods}

\subsection{Materials}

The material used included mutant sorghum Pahat variety and Lactobacillus plantarum FNCC 0027 (obtained from BPTBA LIPI, Yogyakarta, Indonesia), MRS media (de Man, Rogosa and Sharpe; Oxoid, Canada), Folin-Ciocalteu reagent and sodium carbonate (purchased from Merck, USA), Lowry A and B reagent, glucose and tannic acid were purchased from Sigma (Aldrich, USA). All chemicals were analytical grade.

\subsection{Sorghum flour making}

Sorghum flour was made referring to Pranoto et al. (2013). Briefly, sorghum was passed through the process of sorting and cleaning, and then its seeds were separated from their chaff using a husking machine for 5 mins. Afterward, the sorghum was milled and sieved with a 60 mesh sieve.

\subsection{Bacterial starter preparation}

Bacterial starter was prepared according to Utami et al. (2015). It was started from refining the culture by taking 1 Öse (inoculating loop) of pure L. plantarum culture and inoculate into a test tube containing $10 \mathrm{~mL}$ of MRS broth media incubated at $37^{\circ} \mathrm{C}$ for $24 \mathrm{hrs}$ (tightly closed). Pure cultures of $24 \mathrm{hrs}$ old were then transferred to a $4^{\circ} \mathrm{C}$ refrigerator. Furthermore, the working culture was made by transferring $10 \mathrm{~mL}$ of $L$. plantarum culture which had been refreshed into a $250 \mathrm{~mL}$ flask containing $90 \mathrm{~mL}$ MRS broth, then incubated at $37^{\circ} \mathrm{C}$ for $24 \mathrm{hrs}$ to obtain L. plantarum cells of $10^{7} \mathrm{CFU} / \mathrm{mL}$. Cell calculation was carried out using the pour plate method in duplicate. Pure culture of L. plantarum in a $100 \mathrm{~mL}$ (working culture) was centrifuged for 15 mins at 4500 RPM to separate the media and L. plantarum cells in the form of pellets. These pellets were then taken and added with sterile distilled water up to $100 \mathrm{~mL}$ so that ready for use.

\subsection{Modified sorghum flour making}

Modified sorghum flour was made according to Pranoto et al. (2013). Sorghum flour (55 g) was weighed and put in a glass jar, then added distilled water with a ratio of 1: 2 (sorghum flour: water). Starters were added at concentration of $0 \%$ (spontaneous fermentation), $2 \%$, $4 \%$ and $6 \%(\mathrm{v} / \mathrm{b})$. Glass jars were tightly closed and put in a $37^{\circ} \mathrm{C}$ incubator for 10,20 and $30 \mathrm{hrs}$. This condition was chosen according to previous study by Utami et al. (2015). Afterward, modified sorghum flour was dried in the dryer cabinet at $60^{\circ} \mathrm{C}$ for $16 \mathrm{hrs}$. The dried flour was then ground and sifted using a 60-mesh sieve.

\subsection{Measurement of observed parameters}

The observed parameters were evaluated using standard Official Method of Analysis of AOAC (Latimer, 2016), including water content (thermo gravimetric method), ash content (combustion method), dissolved protein content (Lowry method), tannin levels (Folin-Ciocalteu method), reducing sugar levels (NelsonSomogyi method) (Al-kayyis and Susanti, 2016), white color intensity (measured using Chromameter), viscosity (using viscometer), and flour microstructure (using Scanning Electron Microscope).

\subsection{Design of experiment}

The experimental design used in this study was Completely Randomized Factorial Design (CRFD) with variations in fermentation duration $(10,20$ and $30 \mathrm{hrs})$ and the starter concentrations $(0,2,4$, and $6 \%)$ with each treatment consisting of two sample-replications and three repetitions of analysis. Data were statistically analyzed using two-way ANOVA at 0.05 confidence level using Minitab 17.

\section{Results and discussion}

In this research, the testing design i.e. series of fermentation time and starter concentration was chosen according to previous study (Utami et al., 2015). It was reported, the growth of exogenous lactic acid bacteria was known to be stationary at its maximum value since the 2nd hour from the beginning of fermentation. Even until the 24th hour it still hadn't shown declination. And also, exogenous starter concentration of $10^{7} \mathrm{CFU} / \mathrm{mL}$ was sufficient to dominate the bacterial population during the fermentation process.

Test results on physico-chemical parameters of sorghum flour that have been statistically analyzed are shown in Tables 1-3. The graphical 2D contour plots of the results were provided in Figure 1.

\subsection{Water, ash and soluble protein content}

Water content is one of the quality requirements for flour and other food ingredients. The test results showed that fermentation time and starter concentrations have a 

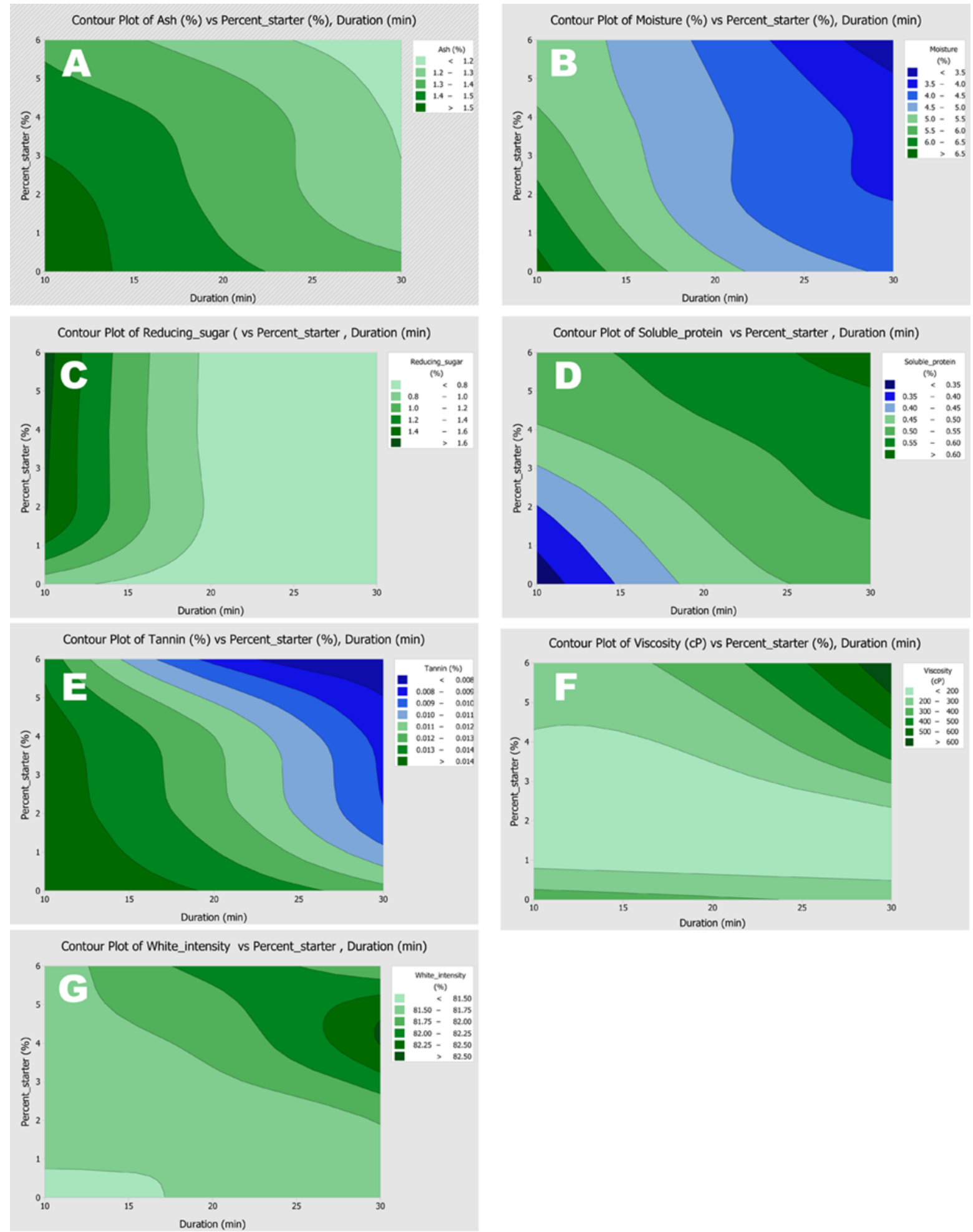

Figure 1. Two-D Graphic Plot showing the effect of duration and starter concentration on physico-chemical properties of sorghum flour. (Effect of fermentation duration and starter on, A: ash content; B: moisture content; C: reducing sugar content; D: soluble protein content; E: tannin content; F: viscosity; G: white color intensity)

significant effect on the moisture content of sorghum flour $(\mathrm{p}<0.05)$ as shown in Table 1 . The water content of fermented sorghum flour decreased as the increasing of fermentation time and starter concentration as seen in Figure 1-B. The microorganisms during fermentation process degraded starch, which caused a decrease in water binding. Whereas the higher the concentration of the starter, the higher the number of microbes that break down the components of sorghum starch so that the bound water will be released, consequently the texture of the material becomes soft and porous.

This condition can increase the evaporation of water during the drying process so that the water content will decrease more in the same drying period (Iswari et al., 2016). The phenomenon was consistent with the previous study reported by Frediansyah and Kurniadi (2016) that said the application of $L$. plantarum on 
cassava flour fermentation reduced the water content in the produced flour.

Analysis of ash content revealed that the ash content of fermented sorghum flour for 10, 20, and $30 \mathrm{hrs}$ of fermentation was significantly different $(p<0.05)$. The longer the fermentation, the lower the ash content in the fermentation sorghum flour produced. The same pattern also occurred when the starter concentration increased as shown in Figure 1-A. It was predicted that fermentation dissolved some nutrients such as vitamins and minerals, thereby reducing the mineral content in flour granules (Narsih et al., 2012). In addition, the more microbes found in sorghum flour, the more minerals consumed by the microbes for growing (Nour et al., 2015).

Furthermore, from the analysis of dissolved protein content, it was found that the duration of fermentation and starter concentration significantly affected the dissolved protein content of sorghum flour $(p<0.05)$. The increasing of fermentation time and starter concentration gave an increasing level of dissolved protein in fermented sorghum flour (Figure 1-D). It was estimated, this is caused by during the fermentation process, microbes hydrolyzed complex proteins into amino acids or simpler peptides in the presence of proteolytic enzyme activity (Amadou et al., 2010).

\subsection{Reducing sugar and tannin content}

The same pattern also appeared in the measurement of reducing sugar levels of fermented sorghum flour. The duration of fermentation for 10,20 , and $30 \mathrm{hrs}$ resulted in significantly different levels of reducing sugars $(\mathrm{p}$ $<0.05$ ). However, the differences in the starter concentration 2, 4 and $6 \%$ did not show a significant difference in reducing sugar content (Table 2). In general, reducing sugar levels decreased with increasing fermentation time both in spontaneous fermentation and in the addition of L. plantarum (Figure 1-C). This showed that besides L. plantarum, which was added from the outside, there are endogenous microbes that are capable of digesting reducing sugars. In spontaneous fermentation, endogenous microbes show high growth since the beginning of the fermentation (Utami et al., 2015). Fermentation longer than 20 mins appeared to give no more decreasing of reducing sugar levels.

Table 2 also showed that the fermentation time and starter concentration had a significant effect on decreasing tannin levels $(p<0.05)$. The longer the fermentation time and the higher the concentration of starter added, gave a lowering effect on tannin content in the fermented sorghum flour produced (Figure 1-E). This was presumably because of there were microbes in sorghum fermentation that degraded tannins. Aguilar-
Zárate et al. (2014) and Setiarto et al. (2015) reported that $L$. plantarum was able to produce extracellular tanase enzymes that hydrolyze ester bonds in tannins to be glucose and gallic acid. With increasing fermentation time, the process of hydrolysis of tannins by the tanase enzyme will be longer. While the increasing starter concentration will increase the amount of tanase enzymes, which causes higher enzyme activity in hydrolyzing tannins.

\subsection{Viscosity and white color intensity}

Meanwhile, in the physical aspects the fermentation time and starter concentration did not appear to have significant effect on the color intensity and viscosity of the flour produced $(\mathrm{p}>0.05)$ in the range of duration and concentration tested (Figures 1-F and G). Nonetheless, there was a tendency for an increase in viscosity along with the increase in fermentation time and starter concentration as shown in Table 3. It was estimated, this occurrence was caused by starch degradation by microbes and a fraction of starch (amylose) was separated and dissolved into fermentation media. The less amylose content or the higher amylopectin content, the starch tended to absorb more water so it became more viscous (Armanda and Putri, 2015). This result consistent with the previous study reported by HanisSyazwani et al. (2018).

\subsection{Microstructure of starch granules}

Scanning Electron Microscopy was used to determine the changes in the microstructure of sorghum flour due to the fermentation process (Figure 2). The observed samples were sorghum flour before fermentation (control) and sorghum flour after $30 \mathrm{hrs}$ fermentation with L. plantarum at concentration $6 \%(\mathrm{v} /$ w). The selection of the sample was based on the results of previous physical and chemical tests, which showed that sorghum flour with $30 \mathrm{hrs}$ fermentation time and $6 \%$ starter concentration produced better properties compared to other combinations.

Figure 2-A shows that the non-fermented sorghum flour granule has a round shape with a granule diameter ranging from 8.68-15.5 $\mu \mathrm{m}$ (11.256 $\mu \mathrm{m}$ on average), starch granules surrounded by a protein matrix forming a dense complex. This was consistent with the previous report that said sorghum proteins formed a matrix attaching starch granules to be a compact structure (Elkhalifa et al., 2005). Meanwhile, fermented sorghum starch (Figure 2-B) has a round shape with a rough surface. The size of the granule diameter ranging from 8.73-16.5 $\mu \mathrm{m}$ (12.4 $\mu \mathrm{m}$ on average) and did not look as dense as non-fermented sorghum flour, which was indicated by the presence of hollow parts between starch 
Table 1. Average values of moisture, ash, and soluble protein content of sorghum flour affected by the fermentation duration and starter concentration of L. plantarum.

\begin{tabular}{|c|c|c|c|c|c|c|c|}
\hline \multirow[b]{2}{*}{ No } & \multirow{2}{*}{$\begin{array}{c}\text { Observed } \\
\text { parameters }\end{array}$} & \multirow{2}{*}{$\begin{array}{l}\text { Duration of } \\
\text { fermentation }\end{array}$} & \multicolumn{4}{|c|}{ Starter concentration } & \multirow{2}{*}{ Average } \\
\hline & & & $0 \%$ & $2 \%$ & $4 \%$ & $6 \%$ & \\
\hline \multirow{4}{*}{1} & \multirow{4}{*}{$\begin{array}{c}\text { Moisture } \\
\text { content } \\
(\%)\end{array}$} & $10 \mathrm{hrs}$ & $6.75 \pm 0.107$ & $6.108 \pm 0.324$ & $5.566 \pm 0.053$ & $5.374 \pm 0.070$ & $5.931 \pm 0.054^{\mathrm{a}}$ \\
\hline & & $20 \mathrm{hrs}$ & $5.179 \pm 0.533$ & $4.609 \pm 0.254$ & $4.570 \pm 0.069$ & $4.351 \pm 0.247$ & $4.677 \pm 0.054^{\mathrm{b}}$ \\
\hline & & $30 \mathrm{hrs}$ & $4.442 \pm 0.341$ & $3.970 \pm 0.304$ & $3.818 \pm 0.297$ & $3.144 \pm 0.043$ & $3.844 \pm 0.054^{\mathrm{c}}$ \\
\hline & & Average & $5.432 \pm 0.062^{\mathrm{A}}$ & $4.896 \pm 0.062^{\mathrm{B}}$ & $4.651 \pm 0.062^{\mathrm{C}}$ & $4.290 \pm 0.062^{\mathrm{D}}$ & \\
\hline \multirow{4}{*}{2} & \multirow{4}{*}{$\begin{array}{c}\text { Ash content } \\
(\%)\end{array}$} & $10 \mathrm{hrs}$ & $1.556 \pm 0.032$ & $1.545 \pm 0.021$ & $1.454 \pm 0.035$ & $1.381 \pm 0.018$ & $1.484 \pm 0.007^{\mathrm{a}}$ \\
\hline & & $20 \mathrm{hrs}$ & $1.424 \pm 0.041$ & $1.372 \pm 0.026$ & $1.353 \pm 0.026$ & $1.245 \pm 0.060$ & $1.348 \pm 0.006^{\mathrm{b}}$ \\
\hline & & $30 \mathrm{hrs}$ & $1.343 \pm 0.012$ & $1.215 \pm 0.030$ & $1.183 \pm 0.012$ & $1.140 \pm 0.029$ & $1.221 \pm 0.006^{\mathrm{c}}$ \\
\hline & & Average & $1.441 \pm 0.008^{\mathrm{A}}$ & $1.377 \pm 0.008^{\mathrm{B}}$ & $1.330 \pm 0.007^{\mathrm{C}}$ & $1.256 \pm 0.007^{\mathrm{D}}$ & \\
\hline \multirow{4}{*}{3} & \multirow{4}{*}{$\begin{array}{c}\text { Soluble } \\
\text { proteins level } \\
(\%)\end{array}$} & $10 \mathrm{hrs}$ & $0.318 \pm 0.016$ & $0.398 \pm 0.021$ & $0.494 \pm 0.025$ & $0.554 \pm 0.055$ & $0.441 \pm 0.007^{\mathrm{a}}$ \\
\hline & & $20 \mathrm{hrs}$ & $0.465 \pm 0.016$ & $0.506 \pm 0.027$ & $0.545 \pm 0.024$ & $0.566 \pm 0.077$ & $0.521 \pm 0.007^{\mathrm{b}}$ \\
\hline & & $30 \mathrm{hrs}$ & $0.507 \pm 0.027$ & $0.556 \pm 0.007$ & $0.568 \pm 0.009$ & $0.641 \pm 0.025$ & $0.568 \pm 0.007^{\mathrm{c}}$ \\
\hline & & Average & $0.430 \pm 0.008^{\mathrm{A}}$ & $0.487 \pm 0.008^{\mathrm{B}}$ & $0.536 \pm 0.008^{C}$ & $0.587 \pm 0.008^{\mathrm{D}}$ & \\
\hline
\end{tabular}

* Values were expressed as Mean $\pm \mathrm{SD}(\mathrm{n}=6)$

A-D The different superscript-letter in the same observed parameter indicated significantly different at $95 \%$ confidence level.

Table 2. Average values of reducing sugar and tannin content of sorghum flour affected by the fermentation duration and starter concentration of L. plantarum.

\begin{tabular}{|c|c|c|c|c|c|c|c|}
\hline \multirow{2}{*}{ No } & \multirow{2}{*}{$\begin{array}{c}\text { Observed } \\
\text { parameters }\end{array}$} & \multirow{2}{*}{$\begin{array}{l}\text { Duration of } \\
\text { fermentation }\end{array}$} & \multicolumn{4}{|c|}{ Starter concentration } & \multirow{2}{*}{ Average } \\
\hline & & & $0 \%$ & $2 \%$ & $4 \%$ & $6 \%$ & \\
\hline \multirow{4}{*}{1} & \multirow{4}{*}{$\begin{array}{c}\text { Reducing } \\
\text { sugar level } \\
(\%)\end{array}$} & $10 \mathrm{hrs}$ & $0.865 \pm 0.056$ & $1.619 \pm 0.067$ & $1.642 \pm 0.053$ & $1.677 \pm 0.031$ & $1.451 \pm 0.009^{\mathrm{a}}$ \\
\hline & & $20 \mathrm{hrs}$ & $0.688 \pm 0.027$ & $0.780 \pm 0.032$ & $0.759 \pm 0.034$ & $0.763 \pm 0.045$ & $0.748 \pm 0.009^{b}$ \\
\hline & & $30 \mathrm{hrs}$ & $0.624 \pm 0.032$ & $0.708 \pm 0.025$ & $0.721 \pm 0.035$ & $0.708 \pm 0.042$ & $0.690 \pm 0.009^{c}$ \\
\hline & & Average & $0.721 \pm 0.009^{\mathrm{A}}$ & $1.047 \pm 0.009^{\mathrm{B}}$ & $1.053 \pm 0.009^{\mathrm{B}}$ & $1.044 \pm 0.009^{\mathrm{B}}$ & \\
\hline \multirow{4}{*}{2} & \multirow{4}{*}{$\begin{array}{c}\text { Tannin } \\
\text { content } \\
(\%)\end{array}$} & $10 \mathrm{hrs}$ & $0.0147 \pm 0.0001$ & $0.0145 \pm 0.0001$ & $0.0144 \pm 0.0002$ & $0.0137 \pm 0.0001$ & $0.014 \pm 0.000^{\mathrm{a}}$ \\
\hline & & $20 \mathrm{hrs}$ & $0.0139 \pm 0.0001$ & $0.0124 \pm 0.0001$ & $0.0120 \pm 0.0004$ & $0.0087 \pm 0.0002$ & $0.012 \pm 0.000^{\mathrm{b}}$ \\
\hline & & 30 hrs & $0.0124 \pm 0.0000$ & $0.0091 \pm 0.0002$ & $0.0086 \pm 0.0002$ & $0.0073 \pm 0.0002$ & $0.009 \pm 0.000^{\mathrm{c}}$ \\
\hline & & Average & $0.014 \pm 0.000^{\mathrm{A}}$ & $0.012 \pm 0.000^{\mathrm{B}}$ & $0.011 \pm 0.000^{\mathrm{C}}$ & $0.0010 \pm 0.000^{\mathrm{D}}$ & \\
\hline
\end{tabular}

* Values were expressed as Mean $\pm \mathrm{SD}(\mathrm{n}=6)$

A-D The different superscript-letter in the same observed parameter indicated significantly different at $95 \%$ confidence level.

Table 3. Average values of white color intensity and viscosity of sorghum flour affected by the fermentation duration and starter concentration of L. plantarum.

\begin{tabular}{|c|c|c|c|c|c|c|c|}
\hline \multirow{2}{*}{ No } & \multirow{2}{*}{$\begin{array}{c}\text { Observed } \\
\text { parameters }\end{array}$} & \multirow{2}{*}{$\begin{array}{l}\text { Duration of } \\
\text { fermentation }\end{array}$} & \multicolumn{4}{|c|}{ Starter concentration } & \multirow{2}{*}{ Average } \\
\hline & & & $0 \%$ & $2 \%$ & $4 \%$ & $6 \%$ & \\
\hline \multirow{4}{*}{1} & \multirow{4}{*}{$\begin{array}{c}\text { White color } \\
\text { intensity }\end{array}$} & $10 \mathrm{hrs}$ & $81.30 \pm 0.141$ & $81.70 \pm 0.004$ & $81.71 \pm 0.161$ & $81.54 \pm 0.095$ & $81.562 \pm 0.055^{\mathrm{a}}$ \\
\hline & & $20 \mathrm{hrs}$ & $81.54 \pm 0.057$ & $81.56 \pm 0.550$ & $81.83 \pm 0.326$ & $82.05 \pm 0.029$ & $81.743 \pm 0.055^{\mathrm{b}}$ \\
\hline & & $30 \mathrm{hrs}$ & $81.50 \pm 0.184$ & $81.77 \pm 0.170$ & $82.51 \pm 0.072$ & $81.76 \pm 0.199$ & $81.887 \pm 0.055^{\mathrm{b}}$ \\
\hline & & Average & $81.45 \pm 0.063^{\mathrm{A}}$ & $81.67 \pm 0.063^{\mathrm{B}}$ & $82.02 \pm 0.063^{\mathrm{C}}$ & $81.78 \pm 0.063^{\mathrm{B}}$ & \\
\hline \multirow{4}{*}{2} & \multirow{4}{*}{$\begin{array}{l}\text { Viscosity } \\
\text { (cP) }\end{array}$} & $10 \mathrm{hrs}$ & $353.25 \pm 29.35$ & $103.25 \pm 6.99$ & $189.75 \pm 7.37$ & $253.75 \pm 22.93$ & $225.00 \pm 5.24^{\mathrm{a}}$ \\
\hline & & $20 \mathrm{hrs}$ & $315.00 \pm 24.73$ & $105.75 \pm 2.99$ & $233.50 \pm 1.91$ & $358.75 \pm 3.95$ & $253.25 \pm 5.24^{\mathrm{b}}$ \\
\hline & & $30 \mathrm{hrs}$ & $273.25 \pm 50.59$ & $155.50 \pm 16.34$ & $461.50 \pm 5.00$ & $674.50 \pm 17.14$ & $391.19 \pm 5.24^{\mathrm{c}}$ \\
\hline & & Average & $313.83 \pm 6.05^{\mathrm{A}}$ & $121.50 \pm 6.05^{\mathrm{B}}$ & $294.92 \pm 6.05^{\mathrm{C}}$ & $429.00 \pm 6.05^{\mathrm{D}}$ & \\
\hline
\end{tabular}

* Values were expressed as Mean \pm SD $(n=6)$

A-D The different superscript-letter in the same observed parameter indicated significantly different at $95 \%$ confidence level.
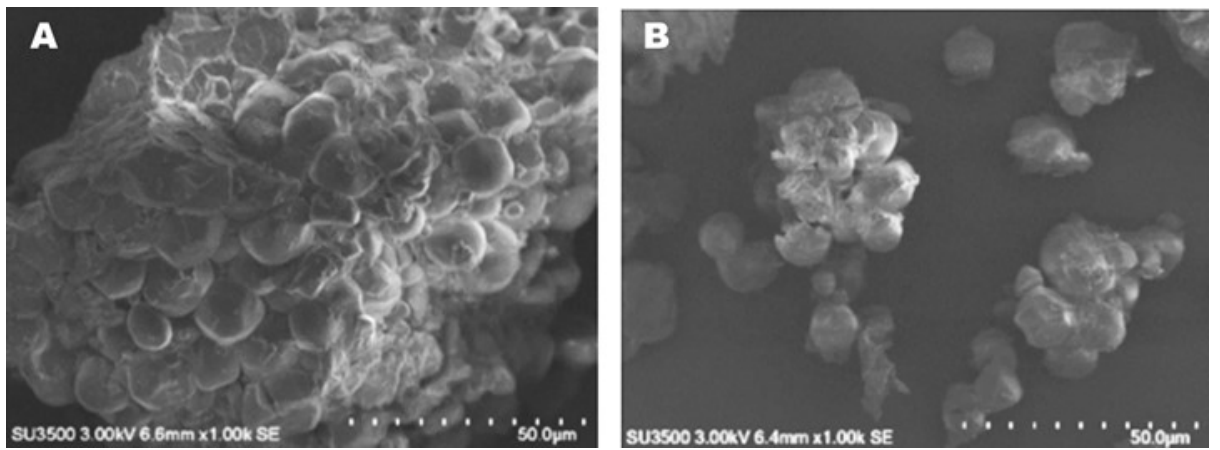

Figure 2. SEM photos of sorghum flour before (A) and after (B) fermentation with the addition of $6 \%$ L. plantarum for 30 hrs. 
granules. The fermentation process that enzymatically broke down proteins and starch was presumably causing this. Proteolytic activity during fermentation removed the protein matrix that envelops starch, resulted in the releasing of its granules (Elkhalifa et al., 2005).

\section{Conclusion}

The treatment of L. plantarum concentration and duration of fermentation had a significant effect on decreasing water content, ash content, reducing sugar and tannin levels, but increasing dissolved protein levels. The fermentation process changed the shape of the starch granules to be coarser and looser than non-fermented one but did not affect its white color intensity and viscosity. This treatment gave beneficial effect on sorghum protein digestibility.

\section{Conflict of Interest}

The authors declare that there are no conflicts of interest regarding the publication of this paper.

\section{Acknowledgments}

The authors expressed their appreciation to BPTBA LIPI for their help and cooperation during the study.

\section{References}

Adeyemo, S.M., Onilude, A. and Olugbogi, D.O. (2016). Reduction of Anti-nutritional Factors of Sorghum by Lactic Acid Bacteria Isolated from Abacha-an African Fermented Staple. Frontiers in Science, 6(1), 25-30. https://doi.org/10.5923/ j.fs. 20160601.03

Aguilar-Zarate, P., Cruz-Hernández, M.A., Montanez, J., Belmares, R. and Aguilar, C. (2014). Bacterial tannases: Production, properties and applications. Revista Mexicana de Ingeniería Química, 13(1), 112.

Alka, S., Neelam, Y. and Shruti, S. (2012). Effect of fermentation on physicochemical properties and in vitro starch and protein digestibility of selected cereals. International Journal of Agricultural and Food Science, 2(3), 66-70.

Al-kayyis, H. and Susanti, H. (2016). Method Comparison of Somogyi-Nelson and AnthroneSulfat on Quantification of Reducing Sugar in Ipomoea batatas L. Jurnal Farmasi Sains Dan Komunitas, 13(2), 81-89.

Amadou, I., Kamara, M.T., Amza, T., Foh, M.B.K. and Guo-Wei, L. (2010). Physicochemical and nutritional analysis of fermented soybean protein meal by Lactobacillus plantarum Lp6. World
Journal of Dairy and Food Sciences, 5(2), 114-118 ref.18.

Arendt, E.K. and Zannini, E. (2013). 8 - Sorghum. In Arendt, E.K. and Zannini, E. (Eds.). Cereal Grains for the Food and Beverage Industries, p. 283-311. USA: Woodhead Publishing.

Armanda, Y. and Putri, W.D.R. (2015). Physico Chemical Characteristics of Fermented Whole Grain Brown Sorghum Flour. Jurnal Pangan Dan Agroindustri, 4(2), 458-467.

Chay, C., Dizon, E.I., Elegado, F.B., Norng, C., Hurtada, W.A. and Raymundo, L.C. (2018). Quality improvement of traditional rice liquor (srasor) processing in Takeo Province, Cambodia. Food Research, 2(4), 299-306. https://doi.org/10.26656/ fr.2017.2(4).038

Craufurd, P., Mahalakshmi, V., Bidinger, F., Mukuru, S., Chantereau, J., Omanga, P. and Hammer, G. (1999). Adaptation of sorghum: Characterisation of genotypic flowering responses to temperature and photoperiod. Theoretical and Applied Genetics, 99 (5), 900-911. https://doi.org/10.1007/s001220051311

Duodu, K.G., Nunes, A., Delgadillo, I., Parker, M.L., Mills, E.N.C., Belton, P.S. and Taylor, J.R.N. (2002). Effect of Grain Structure and Cooking on Sorghum and Maize in vitro Protein Digestibility. Journal of Cereal Science, 35(2), 161-174. https:// doi.org/10.1006/jcrs.2001.0411

Elkhalifa, A.E.O., Bernhardt, R., Bonomi, F., Iametti, S., Pagani, M.A. and Zardi, M. (2005). Fermentation modifies protein/protein and protein/starch interactions in sorghum dough. European Food Research and Technology, 222(5), 559. https:// doi.org/10.1007/s00217-005-0124-9

Ezeogu, L.I., Duodu, K.G., Emmambux, M.N. and Taylor, J.R.N. (2008). Influence of Cooking Conditions on the Protein Matrix of Sorghum and Maize Endosperm Flours. Cereal Chemistry, 85(3), 397-402. https://doi.org/10.1094/CCHEM-85-3-0397

Faith, C. (2017, August 15). Top Sorghum Producing Countries in the World. Retrieved February 10, 2019 from website: https://www.worldatlas.com/articles/ top-sorghum-producing-countries-in-the-world.html

Frediansyah, A. and Kurniadi, M. (2016). Comparative influence of salinity and temperature on cassava flour product by Lactobacillus plantarum and Lactobacillus acidophilus during single culture fermentation. Nusantara Bioscience, 8(2), 207-214. https://doi.org/10.13057/nusbiosci/n080212

Hanis-Syazwani, M., Bolarinwa, I.F., Lasekan, O. and Muhammad Kharidah (2018). Influence of starter culture on the physicochemical properties of rice 
bran sourdough and physical quality of sourdough bread. Food Research, 2(4), 340-349. https:// doi.org/10.26656/fr.2017.2(4).045

Iswari, K., Astuti, H. and Srimaryati. (2016). The Effect of Fermentation Duration on Modified cassava Flour Quality. In Prosiding Seminar Nasional: Membangun Pertanian Modern dan Inovatif Berkelanjutan dalam Rangka Mendukung MEA. Indonesia.

Latimer, G.W. (2016). Official methods of analysis of AOAC International. 20th ed. USA, Rockville: Association of Official Analytical Chemists.

Narsih, Yunianta. and Harijono, H. (2012). The study of germination and soaking time to improve nutritional quality of sorghum seed. International Food Research Journal, 19(4), 1429-1432.

Nour, A.A.M., Ibrahim, A.E.M.M., Abdelrahman, E.E., Osman, E.F., Khadir, K.E., Hussain, N.F., Abdallatif, N.A. and Eldirany, A.A. (2015). Effect of processing methods on nutritional value of sorghum (Sorghum bicolor L. Moench) cultivar. American Journal of Food Science and Health, 1(4), 104-108.

Ojha, P., Adhikari, R., Karki, R., Mishra, A., Subedi, U. and Karki, T.B. (2018). Malting and fermentation effects on antinutritional components and functional characteristics of sorghum flour. Food Science and Nutrition, 6(1), 47-53. https://doi.org/10.1002/ fsn3.525

Pranoto, Y., Anggrahini, S. and Efendi, Z. (2013). Effect of Spontan and Lactobacillus plantarum Fermentation on In-vitro Protein And Starch Digestibility's of Sorghum Flour. Food Bioscience, 2 (3), 46-52. https://doi.org/10.1016/ j.fbio.2013.04.001

Samirana, P.O., Susidarti, R.A. and Rohman, A. (2016). Isolation and 2,2'-diphenyl-1-picrylhydrazyl radical scavenging activity of active compound from Jujube tree (Zizyphus mauritiana Auct. non Lamk.). International Journal of Food Properties, 20, S1523 -S1529. doi.org/10.1080/10942912.2016.1233427

Schober, T.J., Bean, S.R. and Boyle, D.L. (2007). Gluten -Free Sorghum Bread Improved by Sourdough Fermentation: Biochemical, Rheological, and Microstructural Background. Journal of Agricultural and Food Chemistry, 55(13), 5137-5146. https:// doi.org/10.1021/jf0704155

Schons, P.F., Battestin, V. and Macedo, G.A. (2012). Fermentation and enzyme treatments for sorghum. Brazilian Journal of Microbiology, 43, 89-97. https://doi.org/10.1590/S1517-83822012000100010

Setiarto, R. and Widhyastuti, N. (2015). Decreasing
Levels of Tannin and Phytic Acid of Sorghum by Fermentation Using Rhizopus oligosporus, Lactobacillus plantarum dan Saccharomyces cerevisiae. Berita Biologi, 15(2), 149-157.

Suarni, S. (2016). Sorghum Physico-chemical Role on Food Diversification and Industry. Jurnal Penelitian Dan Pengembangan Pertanian, 35(3). Retrieved from http://ejurnal.litbang.pertanian.go.id/index.php/ jppp/article/view/5942

Utami, T., Nurhayati, R. and Rahayu, E. (2015). The Effect of Addition of Lactobacillus plantarum S4512 on The Microbiological and Chemical Characteristics during Sorghum (Sorghum bicolor L. Moench) Fermentation. Agritech, 35(4). 449-455. https://doi.org/10.22146/agritech.9329

Widowati, T., Hamzah, B. and Pambayun, A. (2014). Antagonistic Properties of Lactobacillus Sp B441 and Ii442 from Tempoyak Against Staphylococcus aureus. Agritech, 34(4), 430-438. https:// doi.org/10.22146/agritech.9438

Wiyono, T., Nurrochmad, A., Widyarini, S. and Fakhrudin, N. (2018). The tannin content and antiplatelet-aggregation activity of Cinnamomum sintoc extract. AIP Conference Proceedings, 2021(1), 30017. https://doi.org/10.1063/1.5062741 